\title{
“Index Medicus”について
}

医学图書能 $13(4) ： 239 \sim 248,1966$

津 田良 成*

内 容

I Index Medicus の意義及び歴史

II Index Medicus の収録範囲

III Index Medicus の件名 $\mathrm{MeSH}$ に ついて

IV 索引深度と探索の問題

$V$ 結 論

\section{Index Medicus の意義及び歴史}

世界の医学分野の文献探索に最も大切な二 次資料であり,ひいては医学の研究に欠くこ との出来ない道具の一つである “Index Medicus” の存在の意義は改めてここで述べる までもないであろう。これなくしては“Excerpta Medica", “Chemical Abstracts", “Biological Abstracts” その他の関連分野の 2 次資料を併用したとしても充分には医学全 分野の文献を探索することは出来ない。この 索引誌はその収録範囲が全世界の主要雑誌に 及んでいるために，一つの主題についての研 究をはじめるにあたって，その主題について 過去に書かれた全文献を遡及的, retrospective に探索して，現在その主題について明らかに されている全て, 即ち state-of-the-artを知ろ らとする時に役に立つばかりでなく, 雑誌論 文が索引されるまでの時間的遅れ， time lag といらものが比較的小さいので, 特定分野の 最新の進歩を知る current awareness の活動 にも有効に使元, 且つ主題からの検索のため の索引の構成が技術的にも高い水準を維持し ているので，特定の文献を探索する所謂 specific recall にも適している。

* Yoshinari TSUDA, 慶大医学図畫館
この Index Medicus は現在 National Library of Medicine (NLM) が電子計算機を 使用して行っている文献情報探索システム MEDLARS の副産物といら形で出版されて いる。即ち，毎日々々索引された文献が $\mathrm{ME}$ DLARS の磁気テープ中に蓄積され, これが NLM に要求される機械検索に使用される一 方, 毎月過去 1 力月分の蓄積された文献が GRACE という略称で呼ばれている高速度の Photon 900 photo typesetter により，従来 の人手による探索に便利な形の索引として印 刷されているのである。そして現在の段階で は，MEDLARS それ自身が，本当の意味で の実用には未だあと一歩のところにいるのに 反して, Index Medicus は約 90 年の伝統を 持った索引誌として，益々その質を向上させ ている。

現在発行されている“Index Medicus”は 第 1 巻 1 号が 1960 年 1 月に発行されている が，これを遡って行くと，1879年に始った “Index Medicus”にまで達する。

この歴史的発展過程については既に多くの 人達がいろいろの角度から論じているのでこ こでは述べないが，現在の形に到達するまで には，文献量の増大にともなって必然的に起 った索引作成作業の機械化といらものの各発 達段階を，一歩一歩あゆんで来ているのであ って，電子計算機を利用する MEDLARS の 副産物という現在の形は, 決して一朝一夕に して出来上ったわけではないことに注意すべ きであろら。

従来の, 汪とんど人力にのみ頼った索引作 成方法では，このあたりまでが限度であると 
考えられ，1950年代の後半からは，作成過程 を機械化することにより作成日時を短縮し， より効果的な索引を作成することを目標に努 力が払われ，1958年には，Council on Library Resources, Inc. に対して，その目標の 実現についての資金の提供の申込みがなされ た。その結果 73,800 ドルの資金が与兄られ， NLM は,

(1)年間収録文献数を年間 11 万から，その 約 2 倍の数に増す。

(2)時間的遅れをさらに短かくする。

(3)索引作成過程を孔っと改良して, 編集し たり，配列しなおしたりするのに要する 手間を減らす。

などの事柄を大きな目標として計画し，遂に 1960 年 1 月から新しくIBM のパンチカード に打った文献の書誌的データを，イーストマ ン・コダック社の Listomatic Cameraを使用 して, 早い速度で $70 \mathrm{~mm}$ のフィルムに収め て索引を作成する方法を採用し，このように して作り出された索引に “Index Medicus” といら伝統の古い名前を新たに与えた。この Listomatic Camera の使用は，個々の entry の仕方を統一しユニット化することを必要 とし，ここにきて初めて unit entry という ものがはっきりした形で NLM の索引作業 に取り入れられた。それにともない幾つかの 基本的な調査がなされ，次のようなことが明 らかにされた。即ち，医学雑誌の論文題名の 長さは, 短いもので 1 語から長いもので 37 語 に末でおよび，平均は 10 語であること， 1 語は平均 6.4 字でスペースを各語に一つ取る と 1 題名 74 字分の長さが必要であった。著 者は平均苗字だけで 7.3 字，イニシッルとス ベースを入机て 11.3 字になり，一論文平均 1.5 人の著者がいるので 17 字の長さが必要 である，とか言った事柄である。機械化以前 に於いては，長い索引作業の伝統を持ってい たのにかかわらず，こらいった極く基本的な 数值の調査といらものは案外忘れられていた のである。
さて，この新しい“Index Medicus”の 出現が，積年の索引作成上の諸問題を解決す るかと思われたが，実際に新しい方式で動き 出してみると，その結果は始めの計画とはほ ど遠く，年間索引論文数も約 14 万の数を越 方ず，又，索引作成に要する日数も25日も かかり，この程度の機械化ではとても年間 20 万を越える重要医学論文の索引といら目標に 到達することが出来ないことが明白になっ た。そこで直らに，更に進んだ機械化の可能 性が探求され，その結果到達したのが電子計 算機を使用しての文献探索システム MEDL ARS の副産物のような形で，磁気テープに 蓄えた文献情報を高速プリンターにより打ら 出して索引を作成する方法である。

この新しい作成方法は 1964 年 1 月の 5 巻 1 号から，始められたが，初めに子定された 電子計算機用の高速印刷機 GRACE (photon 900 computer phototypesetter) の開発が遅 れ，1号から 6 号までの 6 カ月分は通常の計 算機用高速印刷機で印刷したため，大文字の 久乙か使用出来ず，且つ外国語独特の発音記 号，その他の記号類も含をれない変則なもの となっている。7 月号のみは, GRACEの穴 らめに急に開発し急いで作った大文字と小文 字の両者が使用出来る高速印刷機が使われて いる。現在のよらな $6^{\circ}, 10^{\circ}, 14^{\circ}$ の各サイズ の大文字，小文字，諸記号類を備えた GRA CE で“Index Medicus”が印刷されるよう になったのは， 5 巻 8 号，1964 年 8 月からで あった。

MEDLARS 本体の機械検索が今一歩とい らところで完全な実用化にまで達していると は言い切れない状態にあるのに，その副産物 として作り出している“Index Medicus”は 着々とその効果をあげだし，現在年間約 18 万 の論文を索引して扣り，1969 年の年間 25 万 の目標も，あながち不可能とは言い切れない 段階にまで達している。

\section{Index Medicus の収録範囲}


“Index Medicus” の収録雑誌数は年々数 を増して扣り，現在では約 2,500誌となり， 1966 年 1 月発行の “List of Journals indexed in Index Medicus”によ机ば，71 力国 の雑誌が含まれている。

2,500 誌という数は，世界で出版されてい る医学雑誌の総数から比べれば決して充分な 数とは言えないであろらが，1950年から60 年までの間に生物・医学関係の雑誌数が $20 \%$ 増加しているのに比べて, “Index Medicus” の收録論文数は $51 \%$ も増加している。他の 主要抄録誌，索引誌類では，その収録雑誌に 載せられている論文といえども，比較的に選 択的に収録されているのに比べて，“Index Medicus”では，一度収録することに決めた 雑誌は，一部の雑誌を除いて，汪とんど全て の索引可能な論文を索引している。例光ば, Orr が行った生物・医学関係の論文を代表し ていると思われる論文の“Index Medicus”, "Chemical Abstracts", "Biological Abstracts” その他の主要抄録誌, 索引誌類での 収録状態の調査によると，1962 年に米国国立 衛生院 NIH が研究助成金を与えた研究の成 果として，891の異なった雑誌に発表された 14,275 論文は, 収録雑誌だけを考えると, “Chemical Abstracts”が 624 誌も収録して いて, “Index Medicus” の場合の 589 誌よ りも多いが，論文そのものの数では，“Index Medicus”のほらが多く，それに収録された 論文は 87\%にも達していた。“Index Medicus”に取録されなかった論文の内訳を示す と,

$\begin{array}{lc}\text { 生物科学関係論文 } & 28 \% \\ \text { 化学関係論文 } & 16 \% \\ \text { 心理学・社会学関係論文 } & 12 \% \\ \text { 歯学関係論文 } & 7 \% \\ \text { 準医学 paramedical 関係論文 } & 5 \% \\ \text { 医学関係論文 } & 7 \% \\ \text { 工業技術関係乞の他の論文 } & 27 \%\end{array}$

となり，純粋の医学の文献で収録されていな かったものは極くわずかであった。しかしこ
の調査は, あくまで米国の医学文献のみを対 象として考えた米国の研究者のための調査で あり，米国外の研究者の立場からその他の国 の医学文献を考えた場合にはこの条件は大き く変ってくる。

日本の医学雑誌は 127 誌収録されで括り, このらち 51 誌は欧文誌である。そして，その 収録誌の選択には幾多の疑問点が存在する。

索引誌というものは, 網羅性も重要である が同時に索引誌のレベルを保つためには，或 程度の収録誌を選択しなければならない。現 在全世界で出版されていると推定される医学 関係雑誌は 5,000 とも 6,000 とも言われてい るが，医学中央雑誌が収録している日本の医 学雑誌のみでも昭和 40 年 9 月現在で, 和文 誌 1,018 , 欧文誌 118 , 合計 1,136 誌もあり, 従って $5,000,6,000$ といら数は既に何らか の基準に従って選択されているものであると 考えざるを得ない。例えば，どの主題分野ま でを医学の範疇に入れるかといらことも選択 の一つの条件であるし，学術専門雑誌のみに しぼるか，一般素人向きの雑誌も含めるかと いらことも選択の条件になり，その方針次第 で「医学雑誌」の数も変化しよう。しかし，

「日本外科学会雑誌」や, 「日本消化病学会 雑誌」のような雑誌がこの 127 誌中に含まれ ていないとすると，この索引誌の収録雑誌の 選択能力といらことに大きな疑問をいだかざ るを得ない。実際に“Index Medicus”の収 録誌の決定は，NLM の索引課が属している 書誌サービス部の部長, 索引課長, $\mathrm{MeSH}$ 課 長, それに米国内の一流の医学図書館員, 及 び医学者夫々数名からなる選択のための ad hoc の委員会により，収録を推薦されたもの の中から NLM の館長が決定することになっ て扣り，元の根底に流れる方針は，出来るだ け世界中の文献をまんべんなく収録するとい うことで，余り医学雑誌を出していない国の 雑誌は，少しぐらい程度が低くても収録する 傾向がある。ところが一方 ad hoc の委員会 が雑誌を選択するに当っては，特に成文化さ 
れた選択基準があるわ列ではなく、これら医 学研究者, 医学図書館員の経験, 李たは勘に 依って行なわれている有様である。従って米 国内での利用の多い雑誌にかたより，日本語 ロシア語など, 語学の面で広い利用をはばん でいる国の雑誌は必然的に選択もれといら運 命をたどる場合が多くなる。そのため，日本 の雑誌の場合を取ってみても, 日本の医学雑 誌を殆んど完璧に網羅している医学中央雑誌 に収録されている欧文誌は, 全収録誌数 1,136 に対してわずかに 10\%弱の 118 誌であるの に, Index Medicus が収録する日本の雑誌 127 誌中には，これが $40.2 \%, 51$ 誌も含まれ ているのは，決して英文誌のほらが和文誌よ りも質的に勝れているためとの理由であると は思われない。

以上，収録誌の選択にはあまり明確な基準 といらものはないが，このことは何も“Index Medicus”に限ったことではない。NLM の副館長の特別補佐で 1966 年 6 月迄 書誌サ 一ビス部の部長であったカレル博士の調査に よると, Chemical Abstracts, Biological Abstracts, Psychological Abstracts,などの 主要抄録誌も，その収録誌の選択には何れも 基準らしいものを持っていないことがわかっ た。学術雑誌の客観的な価值判断というもの が不可能に近いことは，本 紙 12 巻 4 号に発 表された「Index Medicus 収録和雑誌及び 協会加盟館に拈ける重要和雑誌」と題した, “Index Medicus” の収録誌として推薦する 雑誌を決めるための調査の論文でも明らかな と赤りである。

“Index Medicus” に収録されている雑誌 の収録までの時間的遅れは雑誌によって異な るが, Orr が Current List の終りの時期に行 った調査では，米国に於ける心臓血管と内分 泌と精神薬理学の三つの学会で発表された論 文が，雑誌に載ってから，索引されるまでの 時間のずれが大体平均 4 力月ほどであり，索 引誌の時間的遅れとしては，比較的少ない。 然しこれは，詨象となった論文がすべて米国
内で発生したものであり，然もその主題分野 が米国の研究者達の興味を強く示す分野であ るために索引時に於いて一般の雑誌より早く 処理されるよらな状況にあることにもよって いるのであろら。何故ならば“Index Medicus”の索引課は現在, 平均 6 力月近くの滞 貨をかかえているので, 特に一般（米国内で の) 要求度の高い雑誌は「至急」の張り紙を 表紙につけて，特別扱いで早く索引すること を実行している。又そればかりでなく，索引 課の課員の理解する国語の数は非常に多い が，ロシア語，日本語などの特殊語学になる と, 必ずしも常時これらの語学を自由にあや つれる課員を抱えていられる訳ではなく，従 って, これらの 2 力国の雑誌の滞貨, backlog は 1 年近くに及んでいる。そこで考兄られた のが，日本語のよらな特殊の国語の文献は，

日本の医学図書館に委託して, 夫々の国で索 引して蒷い，それを航空便で集めて，MED LARS に入れ “Index Medicus”に打ち出 すといら方法である。この方法によれば理論 的には 1 肫以の遅れで索引することも可 能になる。実際に日本語に関しては既に 1966 年 10 月から 慶応義塾大学医学部図書館でこ の仕事を開始している。そして，若しこのプ ロジェクトが成功すれば，インドその他の国 の文献に詨しても同様な手段が講じられる計 画もある。

“Index Medicus” の収録範囲は前述のと おり，医学雑誌約 2, 500 誌に含まれた論文で あり, この 2,500 誌といら数は “Chemical Abstracts”の約 9,000 誌などに比べて，明 らかに医学分野の雑誌の半数以下であること が推定されるが，“Chemical Abstracts”の 収録誌の場合には，(1)完全に全論文を抄録す る雑誌，(2)大部分の論文を抄録する雑誌，(3) 重要な論文のみを抄録する雑誌，(4)ほと儿ど めったに抄録しない雑誌などのグループに分 けて収録されているが，“Index Medicus” の場合には，特に総説論文のみを選んだりす るよらな一部の雑誌と, 少数の選択的に索引 
する関連分野の雑誌を除外ば，ほ上んど全て の雑誌のすべての論文が索引されている。 索引の対象となる論文は次の種類のもので ある。

1. 原著論文であ机ば，その長さや，文の 形体棌関係なく全部索引する。

2. 医学関係人物の伝記や死亡記事。

3. 臨床病理討議会の記事。

4. 学会などで発表された，相当の長さの ある発表論文。（但し, 学会出席者の印象記 や新聞記事的な文は含まれない)。

5. 実際には論文と考光ら机る上らな論説 記事（新聞の論説的なものは索引しない）。

6. 論文といえるような種類の「letters to the editor $\rfloor$

7. 薬物の副作用についての「letters to the editor $\rfloor$

8. 米国医師会の会議の報告。

9. 会員名簿類

10. “Nature”だとか “Science”だとか 科学分野の新しい説明, 発見, 動向などを伝 えることを目的とした類の雑誌に載せられた 短い記事や所謂「short communication」と いったものの類。

11. 質問応答の類で小論文としての長さ, 形の整っているもの。

12. 誌上討論会

13. 原論文を載せている雑誌が収録誌中に 含まれていない場合の翻訳論文やリプリン 卜。

この様にほとんどの論文が索引刘象となっ ているため，収録されることになっている雑 誌の論文は完全に近いところまで索引されて いる。

“Index Medicus” の他に NLM は,この 年間累積版の “Cumulated Index Medicus” 総説論文を索引して年 1 回出版している “Bibliography of Medical Reviews", 新刊 単行本で NLM が新たに入手したものの書誌 である隔週発行の “Current Catalog”なぞ の出版物, 及び特定の主題とついて, 週刊,
月刊などと夫々異なった周期で出されている recurring bibliography と呼ばれる一群の索 引を出している。これらの共通点は, これら 全ての書誌, 索引が一度 MEDLARS の磁気 テープに入机ら机て，そこから打ち出されて 作られていることである。但し，この中で “Current Catalog”は “Index Catalogue” に収録されてきた資料中の単行本に関する情 報を受けついだ “National Library of Medicine Catalog”の後継者で, 1966 年 1 月に 始めて現在の形になり, 電子計算機に蓄えら れるようになったものであるが，雑誌論文と は異なった in-put の方法を使用しており， 厳密に言党ば MEDLARS と同じシステムに 含まれて居らず，たまたま同じ電子計算機を 使用している二つの異なった情報探索組織と も言い得よう。

“Cumulated Index Medicus” は新 “Index Medicus”が 1960 年に発足した時に, 米国医師会, AMA の出版していた QCIM を廃刊させた代償にとの出版をAMAにゆだ ねたもので, 編集その他の準備一切は, 勿論 NLM で行なわれていたが，今年発行された 1965 年度の “Cumulated Index Medicus” からは出版も NLM で行ならようになった。 “Bibliography of Medical Reviews" は既 に “Current List of Medical Literature" （CL）を出版しているときから始められたも ので，当時，CL に使用した総説論文の書誌 的データを記したカードを再び三度び並べ直 してこの “Bibliography” の原稿を作るのが 非常に困難な作業の一つであったが, 現在は, この編集は MEDLARS のプログラムの一つ により自動的に行なわれている。歯科学, 看 護学, 心臟血管病学など幾つかの分野につい て出されている recurring bibliographies は Index Medicus に収録される論文を MEDL ARS に入れる段階では全く何の相違もなく， ただこれらの書誌類の収録分野に属する件名 のもとに索引された論文は随時引き出せるよ らにプログラムが組んであるだけで, 従って, 
これらの書誌類に含をれている文献は，少数 の特別に追加としてその書誌のみのために索 引されている雑誌の論文以外は全て “Index Medicus”にも含まれている文献である。

\section{III “Index Medicus” の件名 MeSH について}

“Index Medicus” は件名と，著者名その 他の人名のアルファベット順に配列された二 つの部分から成り立って扮り，その件名は通 称 MeSH (Medical Subject Headings) と呼 ばれ MEDLARS のシソーラス, thesaurus でもある。件名という昔からの言葉を使って はいるがシソーラスとして最も整ったものの 一つとされている。現在約 6,600 の主件名と 42 副件名の他に約 7,000の参照が含まれて いる。件名自体は医学各研究分野の動きにつ れて絶えず加えられたり削られたりしている が，傾向としてはやはり年々増加しており， 1967 年にも副件名が 53 となり，主件名も相 当数増える予定になっている。従って, 毎年 1 月に発行される Index Medicus の各巻 1 号の第 2 部として別冊で, 改訂された $\mathrm{MeSH}$ が出版されている。又年 1 回の正規の改訂以 外にも，新たに MeSH に加える必要が認め られた件名は次の正式な改正時期迄，暫定的 な件名として，Index Medicusには使用しな いけれど，MEDLARS のテープの中には韵 えられ，機械検索の場合には使用出来るよう になっている。

$\mathrm{MeSH}$ に新しい件名を加えるかどうか，又 ぞの様な件名を廃棄にするかなどを決定する のは，索引課と同じ書誌サービス部に属する 医学件名課の人達の仕事で，この課は絶えず 外部の学会などと連絡を取りながら，医学の 進歩を正しく反映する up-to-date の件名を保 つことに努めている。

ところで, “Current List”の時代には， この “Current List”のみに使用される Subject Heading Authority List といらものが 1954 年に作られ，これがずっと使用されてい
たが，1960 年に新しい“Index Medicus”に 推移する時に，それなで NLM が“Index Catalogue” や旧 “Index Medicus” や “Current List”を手が惊てきての経験に基 づき，単行本にも，雑誌論文にも同じ件名が 使用出来得るといら考㝋を打ら出し，目録作 業と索引作業の両者に同時に使用するための 新しい Medical Subject Headings の第 1 版 を出版した。この MeSH は, (1)図書の目録 作業で件名をふるために使用した件名の典拠 カードのファイルと(2)Current List of Medical Literature のために使用された Subject Heading Authority List (1954) の両者を参 考にして作られた。

従来は図書の目録作業に使用される件名と 雑誌論文の索引作業に使用される件名とは, その扱ら件名の主題の大きさに相当のひらき があり，一緒には出来得ないものといら考元 が一般に強くゆきわたっていた。然し，NLM ではこれ等を本質的には変らないものとし， 若し雑誌論文の索引にはもっと特殊な, 細か い主題を示す件名が必要であるとするならば 目録作業の場合よりももっと多くの件名を使 用することによって目的を達し得るという立 場をとった。図書館の件名目録作業は，一つ の文献の内容全体を一つの言葉または句でぴ ったり言い表わすような，そういら件名を与 えることであるとする伝統的な考え方，即ち 「これがそのものである」といったラベルを はるよらなものであるとするのでなく，「こ こにこらいらものがある」といった形の指示 するもの (pointer) であるとする，そしてこ の pointer を二つ以上使用すれば非常に特殊 な主題も表現し得るという考えに基ついてい る。確かに自然語といらものは非常に語彙が 豊富ではあるが，あらゆる特殊な事柄，場合 などを一つの言葉で表現出来るほど豊富では ないのは事実であり， pointer といら考光方 に利点のあることもらなづける。

$\mathrm{MeSH}$ の第1版のもら1つの新しい試及 は一定数の副件名といらものを採用したこと 
である。副件名は題目的なもの topical, 地理 的, 時, 語学, 出版物の型などを示す形式や 副件名 (細目) の種類が考号られるが, 雑誌 論文の索引作業で使用されるのは題目的副件 名のみで, その他には各主件名, 副件名の下 に索引された論文を国語のアルファベット順 にグループ分けしているだけである。一方単 行本の目録作業では題目的副件名, 地理的副 件名, 形式副件名の三者を使用している。然 ここの副件名も1963 年から 65 年までは, 中 断されていた。副件名を使用するのは, 主件 名の夕では充分に表現出来ない特殊な主題, 又は主件名の特殊な状態を, もっと適確に索 引するためであったが，電子計算機を使用し ての検索の場合などには必ずしも特に効果的 でもなく，より多くの件名を使用することに よって, 充分に目的は達し得るし, 各主件名 の下に索引された文献を, 文献の書かれてい る国語のアルファベット順にならべると, 副 件名を使用した時と同じ，又はそれ以上の効 果をあげられるといらことが NLM のあげた 中断の理由であった。然し現在の段階では未 だ大多数の人が MEDLARS による機械検索 よりか, “Index Medicus”を使用しての人 手による探索に頼っており，又その仕事を担 当している者の多くが，副件名の廃止にとも なった不便をうったえたので，NLMは1966 年1月の $\mathrm{MeSH}$ から再び副件名を復活させ た。題目的, topical な副件名は一つの主題に ついて繰り返し起こる状況, aspect といった ものを，ひとまとめにグループ分けしたもの で, 例变ば, 著者が一つの器官について述べ るときには, 霓々その器官の解剖学的な面だ とか, 生理学的な面, 疾患の場合, 病理学的 な面などをとり上げるし, 病気について述べ るときには, 病因, 病気の状態での器官の生 理, 治療などの面を強調することが多い。同 様に薬についての文献には, 代謝の問題, 薬 理学的な問題, 治療での使用などについて書 かれたものが多く見られる。そこで anatomy \& histology, physiology, pathology, etiolo- gy, physiopathology, therapy, metabolism, pharmacodynamics, therapeutic use などの 題目的副件名が使用されるのである。

$\mathrm{MeSH}$ に使用されている約 7,000の参照 は, see, see under, see also related, see also specific の 4 種に分れ, 又夫々に対してX, $\mathrm{XU}, \mathrm{XR}, \mathrm{XS}$ の記号で表わされる“より参 照” referred from が示されている。A see B は MeSH の件名に選ばれた言葉Bに対し て，その言葉の同義語Aに与えられる“をみ よ参照”で，例党ば ACETYLASE see ACETYLESTERASE のような形のものであ る。A see under B は，その言葉Aが特殊す ぎて $\mathrm{MeSH}$ の主件名としては使用されてい ないから, Aよりも更に一般的で且つ $\mathrm{MeSH}$ の主件名として使用している言葉Bのもとを 見ればAに関しての文献が見つかることを教 えている。例えば ACETYLDIGITOXIN see under DIGITOXIN といった具合に使用さ れている。A see also related B の場合は, $\mathrm{A}$ 己 B \& $\mathrm{MeSH}$ の主件名として存在してい るが，夫々異なったカテゴリーに属していて 且つ打互いに関連のあることを意味し，索引 作業又は検索作業の場合に，より適切な件名 そ導き得ることを目的としている。例えば， ACID-BACE EQUILIBRIUM (G1,H) see also related ACIDOSIS (C 9, C 13) の場合 若し ACID-BACE EQUILIBRIUM という G1，H カテゴリーのこの件名に近づいてみ て，これから参照されている ACIDOSIS と どちらか求める主題内容に近いものを選ぶこ とが出来る。A see also specific B の場合 は, AV関連してもっと細かい特定の件名 $\mathrm{B}$ が MeSH に含まれていることを示す。例兄 ば PANCREATIC JUICE (A 12) see also specific: CHYMOTRYPSIN (D 5), RENNIN (D 5), TRYPSIN (D 5) の様に, 体液 及びその関連の件名のカテゴリー（A 12）に 属する粠液という件名に関連しては，(D 5) のビタミン, ホルモン, 酵素関係の件名のカ テゴリーに含まれている, 膵液中の醅素の件 
名も存在することを示している。

ところで MeSH の件名はその内容, 性質 に從って解剖学的用語, 生物体, 疾病, 化学 薬品，分析及び診断・治療などの技術，精神 医学と心理学, 生物学関係, 物質科学, 社会 科学，工業技術及び商業，人文，コミュニケ ーション及び図書館学とドキュメンテーショ ン, 人間のグループの名称（例えば大人, 子 供，学生なぞ）などの 13 のカテゴリーに分 かれ，な打医学に直接関係のあるカテゴリ一 は幾つものサブ・カテゴリーに分れている。 そしてこのカテゴリーは索引作業, 検索作業 などを行ならとき $\mathrm{MeSH}$ に含まれた件名を 知るのに役立つ。殊に MEDLARS での機械 検索の基礎となる。

各カテゴリ一, 及びサブ・カテゴリーのも とではそのグループの主件名がアルファベッ 卜順に配列してあり，且つある種の主件名の 下には，その件名の示寸範囲内のもっと特殊 な主題又は物を示す件名が一段下げて示され ている。これは $\mathrm{MeSH}$ のアルファベット順 リスト中の see specific との参照の役をする。 又，件名によっては 2 つ上のカテゴリーに 含まれているものもある。例觉ば，カテゴリ

一 A 1 の件名 BACK を見ると,

\section{BACK}

\section{Lumbosacral Region}

Saccrococcygeal Region

Spine (A 2)

と 3 つの件名がその下にあげられており， Spine はカテゴリー（A 2)にも含まれている ことを示している。そこで（A 2) で SPINE を見ると，SPINE (A 1)

\section{Atlas}

Axis

Cervical Vertebrae Coccyx

Intervertebral Disk

Lumbar Vertebrae

Saerum

Spinal Canal

Thoracic Vertebrae

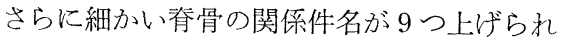
ている。このよらに一つの大きな件名の下に 幾つかの細かい件名が準備され, 更にその細 かい件名の下に，より細かい件名があり，場 合によって更に 1 段階も 2 段階も低い order の件名がある場合，それらの件名のグループ を作り出す generic-specific の関係の構造を tree structure と言って抢り，検索に当って は，この構造を充分にのみこんで打く必要が ある。

MEDLARS による文献の検索のもとをな しているものは機械検索の特徵の一つである 件名のコーディネーションによる検索であ る。ところで繰返して又は常に対になって起 こる事柄（例えば，特定の器官とその病気で あるとか, 器官とその機能, 薬とその薬理学 的効果など）などに対しては，予めコーディ ネーションさせた件名が準備されている。例 えば LIVER DISEASES; STREPTOCOCCAL INFECTION; TUBERCULOSIS; GASTROINTESTINAL の様な件名がこの 類である。副件名の使用はやはりコーディネ ーションの一つの型である。例えば LIVER *anatomy \& histology, であるとか STREPTOCOCCAL INFECTION * diagnosis など がこれである。この他に肝臓のX線治療の 文献のように, LIVER といら件名と共に RADIOGRAPHY という件名を与え，検索 するとともに，この 2 つを同時に満足する文 献を探せるようにするコーディネーションが ある。この場合大概一方の件名は電磁テープ にのみ入れられるが Index Medicus は打ち 出されない。所謂, non-Index Medicus (N IM）の件名である。

\section{IV 索引深度と探索の問題}

MEDLARS の開発は, 前述のように NLM の索引活動がその対象論文の数が多いため機 械化を必要とするようになった結果生まれて 来たものであったが，一旦電子計算機による この文献探索のシステムが動き出すと, Index 
Medicus の出版を早めるといらことに置かれ ていた重点は機械検索システムの改善といら 一大事業に除々にその主導権をらばわれ，現 在においては名実ともに MEDLARSの活動 の副産物のようになってきた。その現れの一 つが前記のコーディネーションのところで述 ベた3つ目の型の Index Medicus に使用さ れないで, 電磁テープにも蓄えられる(NIM) のコーディネーション用の件名の使用であ る。この場合は明らかに “Index Medicus” そMEDLARS 自体の雨者を同時に満足させ ることが出来ないことが明らかになってきて 揖り，索引作業もそのために困難の度合いを 非常に高めているようである。たとえば暫定 的件名 provisional headings と呼ばれる件名 のあつかいなどがよい例である。 MeSH は 前にも述べたと扣り，毎年 1 月に“Index Medicus”の各巻 1 号の pt. 2 として改版さ れて出版されているが，絶え間ない医学の進 歩に合せて MEDLARS の活動を効果的に行 なって行くには，年一回の件名の改訂では間 に合わず，一応暫定的に使用することの決定 した新しい件名は，磁気テープの中に蓄えら れ，機械検索に役立たされているが，“Index Medicus”には, 次の改訂時期に件名として の正規採用が決定して初めて使用される。

MEDLARS の計画の初期の段階では, 索 引対象となった雑誌論文は全て件名が平均 9 から10個与えられることになっていた。 NLM での索引作業の基本的な考光に依ると 大きな項目も小さな項目も，ラベルでもはる ように一つの件名を与えればそれで全てを表 現出来るというのではなく，件名は方向つけ を与えるポインターであって，二つ又は三つ の件名を与えるといった手段によれば，どん な細い主題でもいい表わすことが出来るとし ている。ところで，一般に雑誌論文の主題 は，3から4の件名を用いればどんな細い主 題でも表現出来るといらことを幾つかの調査 が示している。一方 NLM で MEDLARS と “Index Medicus” のために索引する雑
誌論文数は現在年間約 18 万近くに達してお り，1969 年末までに年間 25 万を処理するこ とを目標としている。ところが実際の索引作 業は年々複雑化してゆき，1論文当りの索引 にも時間がかかり，とても全ての論文に 9 つ も 10 もの件名を与交ていられないので，全

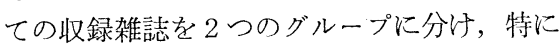
“Index Medicus”や MEDLARS の利用者 にとって重要だと思われる雑誌約 800 誌を索 引深度の深い depth journal とし, 従来どお り 1 論文当り約 9 から 10 件名を与光，他は non-depth journal として 1 論文当り最大限 3 つの件名に制限し, 論文主題のみを索引す ることに決定された。そのようにしてもな お，充分に訓練された索引係が 1 日（7時間 半) に索引出来る文献数は平均 47 である。 従って，1年間 (240日) に 1 人が約 11,280 論文を索引していることになる。すると年間 18 万論文を処理するには，最小 16 名の索引 係と, $4 \sim 5$ 名の検查係 revisor と, 更に数 名のタイピストなどが必要である。

depth journal の論文を索引する場合は, 只たんに論文の主題を索引するだけでなく， その論文の論じている全ての重要な面を完全 に索引する。即ち、それだけ non-depth journal の論文よりも深度の深い索引をすること になる。然しながら印刷にした場合の頁数の 制限から，“Index Medicus”に載せられる のは 1 論文当り 3 件名までで, 従って論文の 主題のみを示す結果となる。

“Index Medicus”を使用して文献探索を 行うときに注意しなければならないことは， この索引方針が器官とその病気という面を最 も主要なものとしていることで, $\mathrm{MeSH}$ の カテゴリーに属している診断とか治療の技術 に関する面は，著者がその技術などを主とし て書いているのでない限り無視されるか, 索 引されても (NIM) として磁気テープのみに 入れられて“Index Medicus”には載せら れないことである。従って，特定の検査によ る結果から，逆にどの様な病気の診断が可能 
かなどといったことに重点を置いて文献を検 索するときには非常な困難にぶつかる。

\section{V 結 論}

“Index Medicus”はその収録雑誌数にも 制限があり，又作成方法が MEDLARS とい う機械検索の副産物として作られているため に種々問題点も多いが，なんといっても現在 外国医学文献を探索する場合には最も重要な 索引であり，またその面では，これ1つを使 用するだけで事足りる場合が多い。然し日本 文献になると，未だ収録雑誌数も医学中央雑 誌のそれの $1 / 10$ をずかに越える程度であ り，乙かもその選択の基準も方法も非常にあ やふやで，從って多くの重要雑誌が収録され ていない結果になって扔り，日本国内で日本 の医学文献の探索を行ならための使用には残 念ながら適しているとは言えない。然し “Index Medicus” は，医学文献を探す場合 に世界中で最もよく使用されている索引誌で あり，従って日本医学文献についても，取録 誌中に欧文誌が多いことが，外国の人達に日 本の医学研究の業績を広く知らせるという面 ではかえって効果的であると言えよう。問題 はこれらの欧文誌の質が他の学会誌に比べて ぞうであるかというところにある。

索引の時間的遅れについては, 日本の医学 文献は 1966 年 10 月から慶応義塾大学の医学. 部図書館で行なわれるよらになったため,こ れから 1 年間程のららには, 過去に NLM が 溜めた 10 カ月以上の滞貨を一掃することが 出来ると思われる。そらなれば，日本の医学 雑誌の論文も，2力月位の拈くれで索引さ れ，印刷されるようになると思われる。

\section{<参考文献>}

1. 福留孝夫 “Index Medicus” の改訂に つい, 医学図書館 $10(1,2): 25 \sim 7$, 1963.

2. MEDLARS Indexing manual. Bethesda, Md., National Library of Medi- cine, 1966.

3. The National Library of Medicine index mechanization project. Bulletin of the Medical Library Association 49 : (1, pt. 2) : 1 96, 1961.

4. Orr, R. \& Crouse, E. M. Secondary publication in cardiovascular, endocrine and psychopharmacologic research. American Documentotion 13 (2) : $197 \sim 203,1962$.

5. 津田良成 米国に和将る医学分野の IR の現状及び日本の対策, Teaching Machine, Training Machine 等の現状動 向調查報告書 第II 部 Information Retrieval System の現状と動向, 日本 電子工業振興協会 1960 (昭和 39 年度 機械工業基礎調查報告書 39-K 562) p. $88 \sim 100$.

6. 津田良成, 裏田武夫, 河辺敦子, 近藤き み, Index Medicus 収録和雑誌及び 協会加盟館に拈计る重要和雑誌 医学 図書館 12 (4) : 231 59, 1965. 